\title{
The Role of the Student Experience in Shaping Academic Writing Development in Higher Education: The Peer Writing Tutors' Perspective
}

\author{
Introduction \\ Íde O'Sullivan \\ Regional Writing Centre, University of Limerick, Ireland \\ Lawrence Cleary \\ Regional Writing Centre, University of Limerick, Ireland
}

On 29 June 2011, 280 delegates interested in the teaching, tutoring, research, administration and development of academic writing in higher education in Europe descended upon the University of Limerick to discuss the role of the student experience in shaping academic writing development in higher education. The EATAW 2011 conference invited all those interested in academic writing development in higher education to contribute to the discussion on enhancing the quality of the student experience through writing. Enhancing the student experience is central to the vision and mission of most higher education institutions in Europe and beyond. How students experience academic writing impacts upon their identities and on their participation in academic and disciplinary environments. Writing programmes and initiatives that actively engage students in the writing conventions and practices of their academic communities can enhance the quality of the student learning experience.

Once the theme for the conference was chosen, the most natural next step was to ensure that, when discussing the student experience, the voice of the students would be represented and listened to. What better way to open the conference than with the voices of student peer writing tutors? With the experience of being both students and tutors, who better to tell delegates about the student experience and the impact of writing and tutoring in writing on that experience? Their voices would set the tone for the event and shape the days of the conference that would follow. Throughout the conference, their thoughts and reflections would act as constant reminders of why we had come together as a group to discuss writing. In voicing their experience, they would remind us that there is much to be learned about teaching from the voiced experience of those we profess to teach. The idea of a keynote panel of peer writing tutors emerged during a stimulating meeting between Leigh Ryan, Lisa Ganobcsik-Williams and ourselves, during the European Writing Centers' Association (EWCA) 2010 conference.

The keynote panel of peer writing tutors brought together a selection of tutors from across Europe to discuss how working as a peer writing tutor has shaped, or is being shaped by, their student experience. Prior to the conference, a call for proposals was sent to writing centres and programmes across Europe which support peer tutoring in writing. In order for one of their tutors to be considered to represent their centre or programme on the keynote panel, centres/programmes submitted a group narrative, reflecting on peer tutoring in writing and the student experience in their context. Peer writing tutors from each centre/programme were invited to write a collaborative narrative of 1,500 words that highlighted the shared experience of student peer writing tutors. Only one narrative was accepted from each European centre or programme.

The response to the call for proposals was overwhelming. More than ten writing centres/programmes from across Europe submitted narratives. Each narrative had an important story to share that shed light on the student experience. Unfortunately, only three narratives could be chosen to be presented as part of the keynote panel of peer writing tutors. An international review committee, set up specifically for this purpose, selected the three narratives that would become the point of departure for the presentation by 
the keynote panel. Selected centres/programmes then nominated the peer writing tutor who would represent them on the keynote panel to discuss peer tutoring in writing and the student experience in their context. The selected peer writing tutors received a scholarship to attend the conference, including travel and accommodation fees. The keynote panel of peer writing tutors certainly fulfilled its objective: it gave a voice to the students, it set a tone for the conference and it gave shape to the conversations that followed throughout the conference and beyond.

That only three narratives could be chosen for the keynote panel of peer writing tutors did not preclude the merit of the remaining narratives. These narratives also had important tutor-student experiences to share. Therefore, it was decided that the collection of narratives and the important stories of these peer writing tutors and students should be captured in this special issue of the Journal of Academic Writing. Seven narratives are published in this collection. We hope that you enjoy the collection of narratives as much as we did and that you learn some valuable lessons about the student experience of writing, as expressed by these peer writing tutors. This collection also serves to remind us of the important work that peer writing tutors do in writing centres and on writing programmes, and it demonstrates the closeness of these peer writing tutors to the experience of the very students to whom we reach out each day in our work.

The first paper that appears herein is the collective narrative presented by the keynote panel of peer writing tutors at the conference: Constanze Alpen, University of Cologne; Lisa Breford, University of Limerick; and Simone Tschirpke, Europa-Universität Viadrina, Frankfurt (Oder). This reflection is followed by the seven narratives written by writing centres and writing programmes across Europe.

\section{Acknowledgements}

We are indebted to the international review committee that chose the three narratives that would form the keynote panel of peer writing tutors, namely, James Donohue, Gerd Bräuer and Leigh Ryan. We are also very grateful for the feedback the committee provided for all of the narratives that were submitted. 


\title{
Looking Back: The Keynote Panel of Peer Writing Tutors at EATAW 2011 in Retrospect $^{1}$
}

\author{
Lisa Breford \\ Regional Writing Centre, University of Limerick (UL), Ireland \\ Constanze Alpen \\ Writing Skills Centre, University of Cologne, Germany \\ Simone Tschirpke \\ Writing Centre of the Europa-Universität Viadrina, Frankfurt (Oder), Germany
}

In the following paper, we will give an overview of the main points of our keynote as we presented it on the first day of the EATAW 2011 conference, followed by a short reflection on the impact that the keynote itself has had on our roles as peer writing tutors and as students.

\begin{abstract}
The development of the keynote presentation posed several challenges. First of all, as we were all based in writing centres in different locations and in two different countries, we only met in person for the first time in the evening before the presentation. Hence, the main parts of the presentation evolved in the form of a long-distance group project, based on oral communication via Skype, written communication via email and collaborative writing using Dropbox to share our documents.
\end{abstract}

Since we felt that the individual structures of our writing centres may influence our experiences as peer writing tutors, we will begin by providing a short overview of each centre and any particularities it had in connection with activities, peer tutoring in writing and peer writing tutor training.

The three writing centres in which we work share similarities in that all set a clear focus on one-to-one tutoring, organise writing workshops and seminars and also offer services for academic staff. However, we also identified some differences between our centres, especially with regard to our training. At the Writing Skills Centre, University of Cologne, the training for aspiring peer writing tutors consists of an oral introduction, observing peer sessions and a written manual with detailed information about themes such as how to instruct students to organize a paper, how to search literature, how to overcome writer's block etc. At the Regional Writing Centre, University of Limerick, tutor training is separated for undergraduate and postgraduate students. While postgraduates take part in a one-day training workshop and receive practical training, the undergraduates are taught to work as peer writing tutors in a fully-accredited module over one semester. And at the Writing Centre of the Europa-Universität Viadrina in Frankfurt (Oder), the tutor training consists of four courses. One of them focuses on creative writing and on learning about writing in autonomous writing groups. Writing groups are supervised by the writing center director. Another course is dedicated to learning more about peer tutoring in writing and process-oriented writing. Both courses are credit-bearing and each lasts one semester. A third 1-2 day course, also credit-bearing, concentrates on intercultural training and prepares students for diversity issues. Lastly the new peer writing tutors receive practical training during which they organize writing groups or workshops by themselves and receive feedback and support from the writing center director and other peer writing tutors. $^{2}$

Although the types of tutor training we underwent differed, in preparing the keynote presentation we came to realise that these differences did not have a major influence on our overall perception of our work as peer writing tutors and its influence on our student experience. Rather, we felt that similarities outweighed

\footnotetext{
${ }^{1}$ Parts of this text have been previously published in JoSch - Journal der Schreibberatung, Ausgabe 3, Oktober 2011, 35-41. Contact: journal.der.schreibberatung@googlemail.com.

${ }^{2}$ In the course of strengthening and fostering peer tutoring as a learning method across the EuropaUniversität Viadrina, the tutor training for peer writing tutors described above has been modified in 2012. It is now integrated in a program that trains students in a basic module in learning issues. In further courses students can then qualify to work as peer writing tutors in one of various fields: e.g. in peer tutoring in writing, language learning, intercultural learning or study organization.
} 
the differences which will also become apparent in the following, when we summarise the common points of our individual perspectives in the context of peer tutoring in writing.

For the keynote panel we set the main emphasis on the following questions: What does it mean to be a peer writing tutor? How does working as a peer writing tutor influence our own student experience? What influence does peer tutoring in writing have on other students' experiences? Below, we have implemented these questions as subheadings.

\section{What does it mean to be a peer writing tutor?}

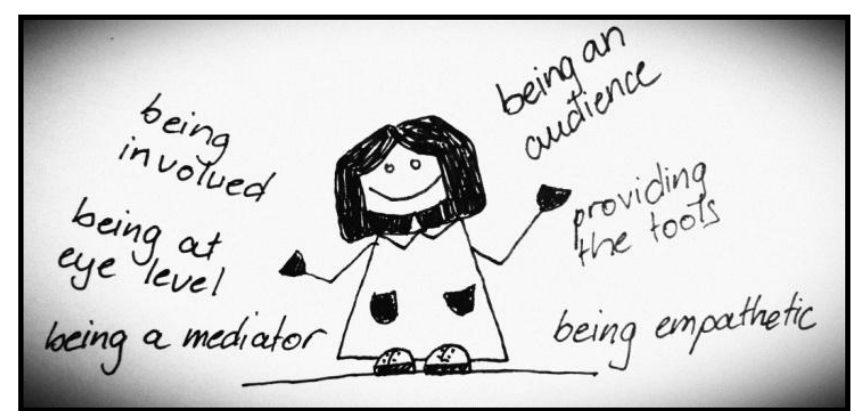

Figure 1: Drawn by Simone Tschirpke

The first task for us as a group was to determine what it means to be a peer writing tutor, based on our own experiences. Peer tutoring in writing has many different aspects, as every student who comes to us has a unique writing issue. In order to be able to relate appropriately, one of the most important approaches for us is to be empathetic. Empathy enables us as peer writing tutors to focus on the particular problems the student is having with regard to his or her work. Depending on the individual student, he or she may require strong encouragement in the form of a timeline to stop procrastinating, or more detailed and on-going support in order to build up self-confidence.

With regard to the latter, but also more generally speaking, it is important that the students do not feel inferior to the person they are talking to. Many students do not approach their lecturers because they think they should know how to master academic writing on their own. They fear that their questions may seem ridiculous. In addition, students shy away from asking for help from the person who will grade their work. However, as we, the peer writing tutors, do not give marks, we put great emphasis on being at 'eye-level'. We collaboratively construct a common ground through sharing experiences and perceptions. As a consequence, most students feel free to talk about their doubts, feelings and ideas which in turn allows us to provide advice from our own experience. During this process, it is essential that the students do not feel anxious. Therefore, we, the peer writing tutors, need to provide an audience that gives them nonjudgmental feedback. By asking the right questions, we aim to enable the students to identify on their own what their writing issues may be. In this way, they themselves can review, for example, whether the structure of their writing is logical and comprehensible.

Furthermore, in our work as peer writing tutors we act as mediators between the academic texts that students have to read during their studies and the requirements of their own course work. Many academic texts are written in a very complex way and can be exhausting to follow, especially for a first year student. Yet, many students assume that they are expected to write in the same style that these texts are written in. Here, it is our task as peer writing tutors to help students to find their own voice and to write in an understandable and comprehensible way.

Sometimes, our role as peer writing tutors is misunderstood as setting goals and providing ready solutions to the students. However, we feel that we only direct the students to the skills and tools which they need to overcome their difficulties on their own. Hence, one can also say that being a peer writing tutor means being a guide or providing the tools.

Another important aspect of being a peer writing tutor is being involved in the writing centre. We all work in teams with several peer writing tutors, and regular exchange about our work within these groups has proven to be very beneficial. In all three writing centres, the team provides a forum to discuss difficulties or new tutoring methods, to share and construct knowledge or to plan new events, seminars or workshops based on individual team members' experiences. Overall, not only the tutors but also the students coming 
to our centres benefit from the additional energy that each tutor draws from regular team meetings and discussions.

Apart from our responsibilities, another aspect of our work as peer writing tutors is the impact that it has had on our individual experiences as students. This will be described in more detail in the following paragraph.

\section{How does working as a peer writing tutor influence our own student experience?}

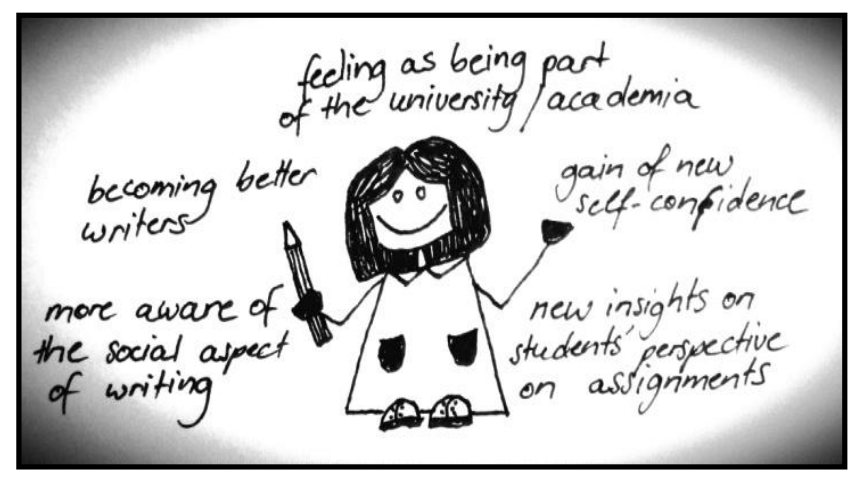

Figure 2: Drawn by Simone Tschirpke.

When discussing the influence that working as peer writing tutors has had on our own student experience, all three of us agreed that we felt a stronger connection with our universities and with academia. The reasons for this are manifold: Being part of the team of peer writing tutors and the writing centre provides us with a strong point of reference within the university instead of just being one student among many.

Through our work in the writing centre, we get to know a growing number of students as well as staff, which makes our lives as students less anonymous. In 2010, for example, the peer writing tutors at the European University Viadrina organized an exhibition which addressed the academic writing of lecturers and professors teaching at the university. They asked professors to write about their writing process, their joys, their challenges and their specific approaches. They displayed those texts along with photos of the lecturers' and professors' writing places in the main hall of the university. With this exhibition they wanted to demystify academic writing and show that writing is a process which can be enjoyable and should be talked about. The latter is also something we discovered for ourselves when working as peer writing tutors in our respective writing centres.

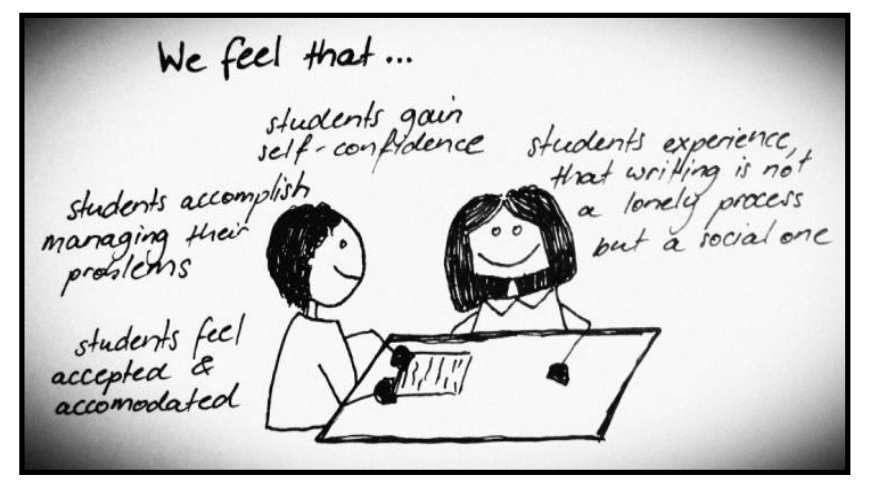

Figure 3: Drawn by Simone Tschirpke. 
Overall, working as peer writing tutors has enabled us to further develop our writing techniques and abilities. This comprises knowing what constitutes a good paper and how to develop it, as well as being aware of the social aspect of writing. In addition, it involves looking for feedback from our peers and lecturers on a regular basis, while we progress through the different stages of the writing process. We have also come to know which environments are the most productive for our writing. All of this has helped us to become better writers.

Furthermore, working as peer writing tutors has also enabled us to gain additional self-confidence. First, we get positive feedback from the students visiting our centres. Second, this gives us new confidence in our own writing abilities. As a consequence, when feeling challenged by our own writing projects, we can draw on the experiences and insights that we gained as peer writing tutors and implement these within our own writing.

Apart from this, another point was specific to the University of Limerick. Here, those PhD students working as peer writing tutors in the writing centre also work as tutors for modules within their discipline. In this context, Lisa Breford, the Irish tutor in the Keynote Panel, felt that having worked on a multitude of assignments with students in the Regional Writing Centre made her more aware of the challenge of designing good essay questions. Overall, peer writing tutors can gain new insights into the students' perspectives on assignments.

For the last point of our keynote, we were interested to explore the experiences of the students who come to visit our centres. We will address this in the following section.

\section{What influence does peer tutoring in writing have on other students' experience?}

From our experience, students in the writing centre feel accommodated and accepted with their difficulties. Issues raised comprise anything from questions of assignment structure to problems with time management to writer's block. Students have told us that they are pleased to be able to ask questions without feeling anxious. Many of them appreciate that we are students at 'eye-level', who invite writers into individualized conversations, ask critical questions, and introduce a wide range of writing techniques, all of which helps students to become better writers. As we are providing the students with the skills and techniques they require, they are imbued with the self-confidence to manage their writing difficulties on their own. During this process, students experience that writing is not a lonely process but a social one, and that sharing thoughts helps to recognize shortcomings and to find solutions.

\section{What influence has presenting as a member of the keynote panel of peer writing tutors had on our experiences as peer writing tutors and students?}

When preparing this narrative to be included in the Journal of Academic Writing, it became obvious that it should also include a short reflection on the keynote panel of peer writing tutors. Such a reflection would allow us to identify the actual effects that the keynote panel had on our work as students and peer writing tutors and that may be generated by similar projects in the future. In the following, we will give a short overview of the points that we identified. In doing this, we will first refer to our experiences as peer writing tutors, followed by those as students.

With regard to the role and work of peer writing tutors, the Keynote Panel prompted reflective processes in two stages: First, within each of the writing centres, writing and preparing the group narratives for submission initiated an intensive discussion between the peer tutors. Second, a dialogue between the three members of the keynote panel evolved while developing the Keynote. As the preparation of the keynote extended over several months, the exchange of ideas within the group took on a rather longitudinal character, leading into a process of self-reflection with regard to our work as peer writing tutors, but also with regard to the roles of our writing centres.

In our role as peer tutors, we learned in different ways while preparing the keynote panel of peer writing tutors. First of all, we realised how much we already knew about writing, about the writing process and about working collaboratively. This knowledge became apparent at different stages of the process; we talked on numerous occasions, as we had learned that communicating about writing is essential. We wrote collaboratively, as we had learned that writing is a social act, rather than a lonely process.

We both accepted and relinquished authority over the presentation as we knew from our experience that doing so was important for giving and receiving feedback. Whenever there was tension or disagreement, 
our experience of working in writing centres proved extremely helpful. We managed to discuss different points of view on, for example, how to approach and structure the presentation, and we reached an agreement.

With regard to our student experiences, being members of the keynote panel of peer writing tutors has had a significant impact. All of a sudden, we were part of the academic community, people were eager to have our input, and they were ready to listen to us. We felt that our experiences and insights as students and peer writing tutors were valued by a huge group of people. In this context, it made a big difference that we were keynote speakers instead of normal presenters: a special emphasis had been put on our perspective - even more so after we had the privilege of opening the conference. This recognition and acknowledgement of our role as peer writing tutors strengthened our confidence as peer writing tutors and as students.

For our personal development as students, our participation in the keynote panel of peer writing tutors also had some more practical effects. We learned more about the difficulties of group work and how to overcome these even when working with people we did not know personally. This will be a valuable experience to draw on during later stages of our academic and our working lives.

To conclude, we feel that the exchange between peer writing tutors, but also among peer writing tutors and the academic community, should be made a priority in the future. While exchanges among peer writing tutors do exist on a national level, for example, in the US and in Germany, we feel that more should be done to encourage an international dialogue amongst peer writing tutors. Until this has become a reality, the following narratives from across Europe provide a valuable insight into the everyday work of peer writing tutors and its multiple effects on the student's experience. 


\title{
Working, Learning, Communicating: The Multicultural Experience of the Peer Writing Tutors at the American University in Bulgaria
}

\author{
Ayjeren Rozyjumayeva, Maya Babaeva, Diana Asatryan and all other tutors (2010-2011) \\ American University, Bulgaria ${ }^{3}$
}

'Every day we discover new characters because checking a paper is, in a way, like reading a novel. The difference is that the hero is sitting next to you.'

Most of us peer writing tutors at AUBG became tutors in our sophomore year and hope to continue until we graduate. Each of us had different expectations about our future experience as tutors. Some of us looked at tutoring as just a job; some wanted to improve their own writing. However, for almost every tutor, it turned out to be a job that required communication and interaction. We found friends and jumped into the challenging world of thoughts.

Being a peer writing tutor here is probably very different from being a peer writing tutor somewhere else. Primarily, the challenge, and at the same time the greatest experience, of every AUBG peer writing tutor is the diversity of the student body. Here there are students from almost forty countries: Albania, Azerbaijan, Armenia, and Bulgaria, Romania, Kazakhstan, Russia, the United States, Serbia, to name just a few. One major challenge for every tutor was getting used to the fact that every tutee writes differently. However, what unites all the tutees is that they translate their thoughts from the language in which they think, and most probably speak, into English. On the other hand, our peer writing tutors are also from different countries. Currently we have ten tutors and they represent six countries: Armenia, Bulgaria, Belorussia, Moldova, Russia and Turkmenistan. Here we have one advantage: it is easier for us to understand what our countrymen want to say and we do not have to spend time trying to figure out tutees' thoughts. Nonetheless, it is never any easier to check the papers of our fellow countrymen because English is not our native language either.

Our work in the writing centre begins at six in the evening. The writing centre is located in the heart of the campus. It is a small study room in the basement of one of the dormitories. Sometimes it is very quiet because there are no tutees. Our experience as tutors taught us to manage time wisely. So, while there are no tutees we do our homework. We have also learned to work more efficiently and faster. When there are many students waiting for a tutor to check their paper, we have to work very quickly, because usually students come a day before they have to submit their papers and as a result there are queues in the writing centre. But we also learn in the process. We came to the conclusion that one should not leave the writing process until the end, because you can see how unnecessary some mistakes are. And they are made primarily because of procrastination and fear of writing.

The majority of students coming to the writing centre are afraid of writing. Every student, including us, has that fear. We are usually afraid because we lack the confidence in our knowledge of the language. Writing even in our native languages is challenging, let alone writing in a foreign language. Consequently, tutees usually do not know how to express themselves.

Sometimes, though, tutees are afraid to write because they do not believe that they can have ideas worth writing about. It may sound strange, but the political situation in the country from which a tutee comes has a great impact on his/her writing. More confident students come from relatively stable countries and they are not afraid of expressing themselves. On the contrary, people coming from countries with more or less oppressive governments suppress their thoughts at some point. They are unsure of the validity of their ideas or just afraid to express them.

The last fear that prevents almost everyone from 'healthy' writing is fatigue. Every student is tired after writing the first paragraph. It happens because we put so much energy into the first paragraph that it wears us out. Instead of writing all ideas down, even in a very raw version, we try to perfect the first

\footnotetext{
${ }^{3}$ Writing Center Director: Filitsa Mullen (fmullen@aubg.bg)
} 
paragraph. As a result, we do not focus on the paper as a whole. We spend a day on the first part and then try to finish the rest of the paper overnight. It is difficult to understand that the first paragraph cannot be perfected because writing a paper is the process of thinking and developing your thoughts in the process.

From another viewpoint, peer writing tutors also have fears. We are afraid to tell tutees that they have to change their whole paper. This is especially difficult when a tutee has put a lot of effort into writing. For example, one tutee wrote about food and how the appearance of food affects our desire to eat. The paper was very well written but it was out of context because his assignment was a comparison/contrast essay while his paper was descriptive.

It is also extremely difficult to comment on some grammatical aspects when the content of the paper is personal. One Albanian girl wrote an essay about the last years of her grandfather's life. Ayjeren, the tutor, could feel her emotions in every sentence. She felt very uneasy when she had to tell the student that some sentences were wrong and that she had to change them. Moreover, the tutor did not know how she could have changed the writing at the sentence level without affecting the intended meaning. Sometimes we are afraid to read papers. We are afraid because we feel incompetent if the paper is in a discipline outside our expertise. For instance, some of us do not know much about politics in Eastern Europe. Reading profound papers makes us feel useless because we cannot comment with more knowledge on the topic.

As with any activity, we are sometimes satisfied or irritated by our job. When we can help someone, we are very happy. However, satisfaction does not come from mere grammar checking. Rather, it comes from communication. We want to communicate when checking a paper. When a tutee listens we can explain what we think and at the same time we can listen to them. As a result we have a dialogue between a tutee and a tutor, rather than a monologue. Or, as one of the tutors put it: "When a person is really listening to the comments, I can see that he/she is thinking and not impatiently waiting for me to, finally, finish revising the paper.' When, sometimes, a tutee comes back with the revised paper, edited according to our comments, or when a tutee does not make the same mistakes after we commented on them, we are extremely happy. It means that we did not just check the paper but also encouraged someone to work more in the future.

On the contrary, we also get irritated. One thing that irritates all our peer writing tutors is sloppiness. Some tutees jot anything down without care and thought. Then they expect a tutor to make a masterpiece out of their paper. Those tutees want you to write down every comment so that they can just include them in the paper and take no more pains with it. Unfortunately, we cannot explain to them that if they come with the paper written in 30 minutes we are unable to make it perfect. Overall, the peer writing tutors give advice, they do not write papers. Usually, this type of tutee also tends to blame us for bad grades afterwards.

However, there are tutees who have thanked us for their good grades. And it is very flattering. People usually like to be flattered. Sometimes, though, we feel guilty because some thanks are not deserved. There are people who write almost perfectly and unfortunately those tutees think that it is only because of the writing centre that they got good grades. We question whether they will be sure of their abilities without the approval of the writing centre in the future.

There is usually one thing that allows all the peer writing tutors to enjoy working in the writing centre. Every day we discover new characters because checking a paper is, in a way, like reading a novel. The difference is that the hero is sitting next to you. It is exciting because one can read the character of a person from the paper. For example, when you see a paper in which misspelled words have not been corrected, you can imagine the way a tutee wrote the paper: he/she might be a person who chats on Skype while writing; he/she could be a person who was in a rush to go somewhere; or he/she may be a person who was so into writing that he/she forgot about minor misspellings.

We can also travel across countries and see a variety of cultures, ideas and thoughts. It is as if the thinking process of students is broadcast on television. This experience is different even in comparison with actual travelling. When we travel, we can see only the consequences of major events in a particular country. Here we see new countries, for us, through the eyes of people who come from those places. We are allowed to see the world from inside. 
Being a peer writing tutor is, therefore, a learning experience in so many ways. Not only do we help students understand the process of writing better, but we as tutors learn how to think and write better ourselves and to understand our world better. For example, the experience of working teaches us to argue reasonably. When you see that a tutee is very one-sided, the only way to challenge their ideas is to question them by representing the other side of the argument. Another advantage for us is the chance to see what is of interest to students our age from other countries. Their interests allow us to compare the ways in which young people from around the globe are different from or similar to each other. Sitting in one room and reading through others' thoughts has taught us what it is to be part of other worlds and how writing and reading carefully can give us insights about the larger world we all occupy in the microcosm of AUBG. 


\title{
Narrative for the Keynote Panel of Peer Writing Tutors at EATAW 2011
}

\author{
Anna, Anna, Annika and Jantje \\ University of Bielefeld, Germany
}

\begin{abstract}
This article gives an interesting insight into a meeting between some trainees of a peer tutoring in writing class and some active peer writing tutors, who are still working in tutoring. In this meeting, the trainees have the chance to ask for lots of information about peer tutoring in writing, and they learn more about the beginning and the development of the peer tutoring program at the University of Bielefeld. Furthermore, the experienced peer writing tutors explain how they work and what kind of concerns the students bring to them. The tutors also describe the characteristics of their tutoring in pairs. Finally, the group of trainees and active tutors talk about their experiences and the benefits of working as a peer writing tutor.
\end{abstract}

\section{'skript.um' - The Peer Tutoring Program in Bielefeld, Germany, Invites you to Take a Glance at our Work}

We are a group of peer writing tutors, working at Bielefeld University for a student tutoring program named 'skript.um', which is part of the Writing Lab. In our team, there are 11 tutors plus a coordinator, who is a member of the Writing Lab. We offer a walk-in service and three writing groups for students. At German universities, it is highly unusual to talk about writing. Unlike in most English-speaking countries, German students do not get weekly assignments but rather writing tasks, most of which are due by the end of the term. We have different types of texts to write, such as research papers of 15 to 25 pages, written final exams and master's theses with 60 to 100 pages.

During the Bologna Process, academic teaching was reformed, i.e. by restructuring degree programmes, creating transparency of studies and qualifications, and refocusing universities towards lifelong learning. Overall, there is now an orientation to competence - called 'a shift from teaching to learning' - in German academia. In the course of this reform, the exam methods and the demands made of the students changed. For example, new genres such as the essay were established at German universities after the Bologna Process. Students need help finding a research question, narrowing down the topic, structuring the project, managing their time and organizing themselves - in short, planning the entire writing process. We offer help for students from all faculties, so you could say it is a 'writing-across-the-disciplines approach'. As peer writing tutors we try to create an environment of interactive and collaborative learning. Opening a new space for exchange about the writing process is our main task. We can offer different support but we cannot establish new thinking.

Every second term, new potential tutors take part in an orientation session. These newcomers have a lot of questions and like to hear about the experience of the 'old-timers'. Now imagine the following situation: a meeting between some trainees of the peer tutoring in writing class and some peer writing tutors from 'skript.um'. We have three writing tutors - Jantje, Annika and Anna - and some tutors-to-be, called trainees here. So let us jump into the exchange between trainees and tutors:

Trainee: $\quad$ So, how did you start peer tutoring at Bielefeld University?

Jantje: $\quad$ Well, we started out in autumn 2008, when we offered the first 'skript.um' walk-in service four days per week. That was an amazing start, but it took a long way to get there. First, we invited colleagues from the U.S. who helped us to get an idea of peer tutoring. With University funding, our director Christiane started to develop a peer writing tutor program. The first step was to hire five students to work together as tutors. Annika and I were two of them. To develop new skills in tutoring writing, we took part in a European writing conference. Furthermore, we shadowed writing consultation sessions, read books about peer tutoring and practiced mock tutorials with feedback on each other's performance. Mostly, it was learning by doing.

Trainee: What about the name 'skript.um'? What does it mean? 
Jantje: $\quad$ The name 'skript.um' combines two different meanings. On the one hand, it is the Latin word for 'writ' or 'composition'. That is the base of our work: the written text. On the other hand, it implies the combination of the words 'skript' and 'um'. They appear in the German sentence 'Das Skript geht um.' which means 'The script goes around.' That is the aim of our work: share the texts for discussion.

Trainee: $\quad$ How do you work? I daresay many students come with the expectation of you finishing their papers for them.

Annika: $\quad$ Actually, some do. At first it was hard for me to say no. We do support them and provide feedback on their texts, if it is sought. During the tutoring session, we do writing exercises, ask questions about their texts (like 'How did you solve problems like this before?') or give some input about writing processes. But every student is responsible for his or her own text. When tutoring, we work on the text together; we work on every single step and help them to develop their own writing strategies. It is like taking them by the hand to lead them on their own way to finish the paper.

Trainee: $\quad$ How does it work to help students from disciplines other than yours?

Anna:

Actually, most of the time it works just fine. Central aspects of writing - such as the writing process or writing exercises to find a topic - don't differ between the fields.

Jantje: $\quad$ Yes, it is basically the same questions in all academic fields: How do I start? How do I work with literature? Which step follows next? To answer these you don't need to know about the topic itself, but rather about different methods to help students into writing.

Trainee: What is special about the peer tutoring approach here in Bielefeld?

Annika: I think our specialty is tutoring in pairs. We have two tutors in one peer tutoring session. This is helpful for us, since we can complete each other's ideas and get feedback on our tutoring. And of course, two tutors might come up with more good questions and a broader view on the topic of the individual tutee.

Trainee: $\quad$ What do you do if you've got different opinions in your tutoring in pairs?

Anna: It depends. Most of the time, I find it very helpful to share different opinions with the writer. Often, in writing there is no 'right' or 'wrong' but rather alternatives between which the writer has to choose. So if the tutors have different opinions, the discussion between tutors and writer - which alternative he prefers and why, or what other alternatives might exist - can give the writer an insight into the writing process and himself as a writer. In this way, our discussion is a really scientific dialogue where positions differ.

Trainee: Jantje: Do you benefit from your work as a peer tutor in any way?

Well, we are still students just as the tutees are. We have to complete the same academic tasks and have to write exams. Therefore, we are familiar with the tutees' problems, because even we have these problems. Over time, we develop our ability to address these problems, a skill that is useful for our studies and our prospective professions. During my work as a peer tutor, l've learnt to reflect my learning and writing process. I figured out which kind of writer I am and how I can structure my writing projects.

Trainee: It sounds as if working as a peer tutor will improve my own student experience. Is that right?

Annika: $\quad$ Yes, it can. From my point of view, you acquire many tools and techniques that can facilitate your writing. Above all, we benefit enormously from our teamwork. It helps us to understand how to give and receive criticism. Working in a team requires agreement and reliability. All of these qualities are helpful in my everyday life as a student, because I can work together with other students in a productive atmosphere. 'Skript.um's' offering helps to create a culture of learning, which isn't very common at German universities. The tutoring exposes students to the process of giving and receiving feedback. If the tutees have a positive experience, maybe their perception of academic studies changes

Trainee: $\quad$ How do you act during tutoring? Are you a fellow for the consultee?

Anna: I don't see myself as a fellow student in my role as a tutor. In their book The Bedford Guide for Writing Tutors (2006), Leigh Ryan and Lisa Zimmerelli speak about 'the many hats tutors wear'. I think this text describes a tutor's role during tutoring very precisely. You cannot define the role of a tutor in a single word because it changes with every tutee. Your role can even vary during the same session.

Annika: In most cases, we take the role of the Questioner. People are often able to solve some of their problems on their own, when they find themselves in a situation where they have to describe their projects and interests very precisely to an outsider. And even if a problem is not solved in that moment, we just have to know what kind of issues we are confronted 
out some very detailed problems and questions which we can address step-by-step.

Trainee: $\quad$ So, does that mean that once I've learnt the techniques about writing, I know everything in a moment?

Anna: $\quad$ First, there is so much to learn about the writing process and tutoring - helpful questions, exercises, theories, research, etc. - so learning never stops. Second, every writer is different. Just because an exercise worked just fine with one writer, it doesn't mean it will work with another.

Jantje: $\quad$ You live and learn. We improve our skills during ongoing trainings, which we organise ourselves or for which we invite experts of several topics to share their experience with us.

Trainee: $\quad$ But you also got training like us in this class?

Jantje:

Yes! What have you learned so far?

Trainee: $\quad$ First, we learned to regard writing as a process. Beforehand, I did not even think about which steps might help me write my papers. I also really enjoyed talking about the different type of writers. Finally, I do not have to fit into just one right way of writing. It is absolutely okay to create my own style. We practiced responding to different needs in a mock tutorial. Luckily, I also had the chance to observe a real peer tutoring session, where I again learned so much, especially how to make use of the different writing exercises in the tutoring process. But now I wonder: how do you work together outside of the tutoring sessions? You have team meetings, don't you? How do these meetings work?

Anna: $\quad$ Team meetings take place every fortnight in our office for $1 \frac{1}{2}$ hour. We take turns acting as the moderator for the meeting. Our meetings have a certain structure: First, we check the organizational part of the meeting and how we are. The next item on the agenda deals with our current tutoring. Every tutor or team can tell the others about the frequency of their tutoring during the walk-in service and what's going on in the writing groups. Sometimes we discuss problems and sophisticated consultees. Occasionally, cooperative tutoring arises out of this, so we can help each other.

Trainee: $\quad$ So you students do a lot. What does the 'backstage-director' do?

Jantje: I wouldn't call Christiane the 'director', she is rather a coordinator. Skript.um has a good working atmosphere where everyone has the same rights and duties. Of course, behind the curtain she manages the finances, does future planning and cares for the staff, which includes our training and supervision. But everyone feels equally responsible for the project.

As you can see, our team - like all peer tutoring in writing teams - focuses on working on texts with students in a cooperative way. By German standards, we have a rather sizable team of tutors, which allows us to counsel in pairs and to give and receive feedback constantly. Because we have both old and new members in our team, we are always able to learn from one another. Finally, we are all honest and upfront with each other and we appreciate everyone's hard work. The team atmosphere is very enjoyable.

\section{References}

Ryan, L. and Zimmerelli, L. (2006) The Bedford Guide for Writing Tutors. $4^{\text {th }}$ edn. New York: Bedford/St. Martin's. 


\title{
Keynote Panel of Peer Writing Tutors EATAW 2011
}

\author{
Constanze Alpen \\ University of Cologne, Germany \\ Daniel Philipp Weyers \\ University of Cologne, Germany
}

\begin{abstract}
Academic writing is one of the elementary techniques for sharing knowledge within the academic community. Somewhat surprisingly, therefore, our institution - the Kompetenzzentrum Schreiben at Cologne University - has had to realize that teaching students the underlying structures and the basic rules is often one of the most neglected areas. Writing centres, writing classes or peer-support have only recently started to appear in universities. Our personal experience, as students at our university and of speaking with visitors at our writing centre, shows that students are rarely offered advice on academic writing in regular university courses or given the opportunity to acquire writing competence through lessons. This is often the result of time constraints of the lecturers; some lecturers even regard academic writing as a qualification that cannot be acquired, but should simply be a prerequisite for enrolling at the university. In most cases, writing competence is taken for granted in academia, without giving the issue further thought. Accordingly, professors and lecturers overlook the fact that only a small fraction of students have come into contact with academic writing in their life before entering university. Of course, some students may already have mastered the patterns and structures of academic writing quite well, but the majority lack those insights and thus continuously struggle with the concept. Many students, for example, are too preoccupied with the abundance of information on their specific topic to pay attention to formalities and structure, even though a clear and logical structure is a precondition of a comprehensible, and thus successful, piece of writing. We can help them by showing them how to structure thoughts, information and arguments in a way that makes them accessible to other individuals of the same discourse community. In the process, we can show them that academic writing is neither an esoteric practice nor solely bound to talent, as many of our students hold it to be, but rather a technique that can be taught and learned.
\end{abstract}

Our peer tutoring in writing programme has proven quite fruitful indeed. With us, students are often more open about their true problems and difficulties with regard to writing and far less inhibited than they would be if conferring with lecturers, who often lack the time or patience to provide extensive help in matters of writing. The same often applies to their acquaintances or friends. Moreover, most students who consult us appear to have little idea of what academic writing is all about. It was rather unsettling for us when we conducted a survey on what students think about academic writing: results showed that a majority of students actually believe that eclecticism, information overload, long-windedness and obscurity are the keys to a good paper. It takes a lot of convincing to show them that academic writing does indeed have a purpose beyond demonstrating who is able to use a thesaurus or follow a three-page-sentence, and is rather meant to present and convey knowledge. Particularly confusing for some of the students who use our service is the fact that the published texts they read frequently deviate from what we recommend.

One awkward question that we often have to deal with is that of our competence. From the visitor's point of view, we are little more than lay readers considering a subject which we are often unfamiliar with. It is a painful moment when one's qualification as a peer writing tutor is questioned. Particularly at the beginning of a session, this can catch one off-guard. However, our response is both short and simple. First, we inform the students that academic writing follows very similar structures no matter what the subject - at least those types of academic writing that are meant to be read and understood. Second, we make it clear that it is the student herself, or himself, who is responsible for achieving the desired improvement; our role is primarily to ask the right questions. For example, if we ask for the purpose and the aim of a paper and the answer we receive is merely a grunt or a look of desperation, it is clear that an underlying structure may be amiss. If the writer is unable to explain to us what he or she means without making leaps in logic, contradictions and the like, he/she often realises for himself/herself what the value of our service truly is.

Things do not always run smoothly, however. Some cases are definitely more problematic than simply asking a few questions to put people on the right track again. Some of our clients have almost succumbed to feelings of despair and utter helplessness when it comes to finishing, or even starting their papers. We 
can recall one client who intended to write about coffee production in Central America, but failed to narrow the issue down to something more tangible than giving a thorough account of anything that was related to coffee production in the first place; he was also determined to focus, if focus is even the right term, on all of Central America. Thus, he kept reading and acquired an expert knowledge of coffee, the effects different types of soil have on the taste, the differences between types of coffee beans and so on, while his paper slowly turned into a bottomless pit. Needless to say, he had not written a single syllable before he came to us. The issue of how to find a subject narrow enough for an academic paper is a common problem which lecturers cannot always remedy, again mostly due to time constraints. A larger number of students are quite unfamiliar with creating an underlying question or thesis, which frequently results in great discomfort, and they unnecessarily lose faith in their abilities as writers. Sometimes they even abandon their studies altogether. A simple question, such as 'are you certain that you are going to write about ALL of Johann Wolfgang Goethe's works and provide the reader with a detailed biography in a fifteen-page paper?' may be quite sufficient to help the student recognise the problem at times; yet in other cases a lot more time and work has to go into helping students regain self-confidence before the issue of writing can be addressed. What we have seen so far is that the emergence of self-doubt could be prevented simply by teaching students the basics of academic writing at a very early stage.

However, we cannot rely on peer tutoring alone. It would be quite impossible for us to teach every single student about the inherent structures of academic writing and the different steps that need to be taken before starting to write. Our service is limited to students enrolled in the Faculty of Humanities and the Faculty of Philosophy; therefore, we are not permitted to offer university-wide writing preparation courses, which we consider an integral part of any academic field. Thus, we have devised a project we call 'cooperative teaching' - this benefits everyone involved in it. We usually take over a regular session of one particular course or seminar to talk about basic issues, such as how to write a paper, how to give a presentation, ways to manage time efficiently and more. This has several advantages: we reach many more students than we would through one-on-one tutoring alone; we give ourselves the opportunity to deal with the more specific and individual problems of each client in our regular tutoring sessions; we prevent students from choosing approaches to writing that are doomed to failure; and, finally, we support the lecturers in their work. 


\title{
Narratives for the Keynote Panel of Peer Writing Tutors
}

\author{
Technische Universität Darmstadt, Germany
}

In order to write a narrative for the keynote panel, we dealt with the question of what it means for us to be peer writing tutors. We also reflected, in which way working as peer writing tutors had an influence on our own student experience. The following narrative is a summary of the ideas, perceptions and experiences of our tutor group.

\section{What does it mean to be a peer writing tutor?}

Being a peer writing tutor involves many different aspects. One of the most important points is the fact that a tutor has to keep in mind that every client is unique. It is important that any advice given must be tailored to the individual needs and characteristics of the clients we are helping. The differences between clients often appear before the consultation even begins. Three times a week, our Writing Centre offers open office hours to all students. The students regularly take this offer, though each approaches the situation in his or her own way. Some will stand shyly at the door and appear unsure as to whether they have the right room - or the right question. Maybe they are asking themselves if it was right for them to seek help from this unknown source. These clients must be first encouraged to come in, then to sit down and to explain why they need our help. If it turns out that they are in exactly the right place and that we can help them, we are always relieved. Other students, who are seeking help, storm authoritatively into the room. They are hardly in the room, their jackets still on, not really ready to start, and they are already trying to describe their problems. They need help, preferably right then. With these clients, we try to first take on the challenge of calming them. We ask them to sit down and then ask what expectations they had of this meeting. What do they need to write? What for? When is the deadline? Where do they need help? This enables us to develop a conversation and structure for the consultation.

Being a peer writing tutor also means noting that each client has his or her own writing process and, therefore, also his or her own writing style. As a result, we do not actually do much to the text or the ideas of the client. This is often a hard path to follow for most of us, as we tend to offer tips, techniques, and strategies to the person that we are helping, while still not imposing on his or her style. A good tutor listens attentively to the client and poses questions so that he can better understand the problems the client is having.

As peer writing tutors, we always try to make the client feel comfortable so that he does not fear talking about his writing difficulties. Therefore, we must view the difficulties of the client not as unimportant but as a serious concern that is really bothering the client and for which we should work together to find a solution.

Moreover, we think that a good tutor has to be able to handle frustration. Some students do not actively participate in the consultations and will not take on any of the suggestions we make. Others have so many problems they wish to work on that they cannot all be solved in one sitting. And yet others come so close to the deadline for their project that they do not get the adequate help they need but just a little support with their most urgent problem.

Being a peer writing tutor also means never finishing learning. There are still so many things to learn for each of us. We think there is no ending point where we can definitely say that we are trained peer writing tutors. The learning process does not end as long as we are actively tutoring.

\section{In which way has working as peer writing tutors had an influence on our own student experience?}

Working as peer writing tutors formed us in a crucial way. We learned a lot of things that had an impact on our own student experience and that we will also use in our professional life. The points we carried together in our group can be classified in three aspects: knowledge of our training to be a peer writing tutor, experiences gained with teamwork and experiences formed by interaction with clients in consultations. Through our training to become peer writing tutors, we have learned many new things. First of all, we have acquired theoretical knowledge and practical strategies we can use to improve our own academic writing. Aside from the acquisition of theoretical knowledge for writing and writing teaching, we 
became familiar with various communication techniques and, through constant contact with our clients, we expanded our social and methodical competence. We realised that a flexible and open attitude is extremely important for a good or successful consultation, especially as we have clients with different cultural backgrounds. This tenor lead to new self-confidence that arose out of the cooperation with other students in our courses at university.

There is another fact that had a positive influence on our cooperation with other students - what we always like about being peer writing tutors is working in a team. This is the place to share the good and bad experiences. One is not left completely alone to handle the tutoring session if it gets tricky. When needed, we can always ask the others to help out, ask them for advice or discuss difficulties on our team supervision. Here, we review past appointments and try to find new ways to help our clients. After each meeting we leave with new ideas and a lot of motivation for the next sessions. These experiences fostered our motivation for teamwork in general.

The interaction with a lot of different clients had great influence on our own student experience. That we work with the clients in a 'peer-setting' is an important factor for us because it allows encounters at the same level. When we started tutoring, we could hardly imagine offering help to students from other fields. We found out that we as peer writing tutors do not need to be studying the same thing as the client to be able to give out good advice. Working with clients from other fields can be a great enrichment. We gained insights in a lot of different subjects our clients were writing on. Furthermore, we learned something about the working methods in other fields of our university. We feel a stronger connection to our university. 


\section{From Dusk Till Dawn}

Ariane Hoyer, Luise Herkner, Patrick Kowal, Franziska Liebetanz, Juliane Patz, Nora Peters, Mandy Pydde, Anja Poloubotko, Sebastian Schönbeck and Simone Tschirpke Schreibzentrum der Europa-Universität Viadrina, Frankfurt (Oder), Germany

It was a deep dark Thursday night in March but the lights inside the writing centre (WC) at the European University Viadrina (EUV) were still switched on. Normally, the night guard would have locked the doors by then. However, on the night of March 18th 2010, this routine was broken. That night, the doors stayed wide open because the WC had invited students to participate in the event 'Long Night of Postponed Papers'. ${ }^{4}$ The initial idea for this event came from a student, who commented that 'actually, it would be great if tutoring sessions in writing would be offered all night long.' And this is exactly what happened from dusk till dawn!

In this narrative, we are using this very special event to illustrate our understanding of peer tutoring in writing and writing centre work. The team of the WC at the EUV is committed to improving writing centre work and meets every two weeks in order to discuss tutoring sessions, new events and projects. Additionally, we meet for further advanced training in the field of writing centre work once every month. To expand our knowledge of writing practice and writing research, we also attend international conferences. Consequently, our centre is a place for students at any level of education and writing ability. In fact, the mixture of know-how and curiousness, and the commitment of the WC team members, often nurtures ideas such as the 'Long Night of Postponed Papers'.

The 'Long Night of Postponed Papers' was created as a special event for students. By offering our tutor services at night and during the winter break, we wanted to raise awareness of the problems caused by procrastination. Procrastination is a phenomenon everyone experiences once in a while. Many students ask for tutoring sessions at the very last minute. Often, they tell us that they have been struggling for weeks to find a good research question, a hypothesis or an adequate structure for their writing.

On the one hand, we wanted to remind students that delaying the work and hence the writing until the last night before a paper is due is never an efficient approach to a writing project. We wanted to show what happens when students write their papers in the middle of the night, suffering from enormous pressure and stress.

On the other hand, we also wanted to show the positive effects of working in companionship with other students. We wanted to highlight the advantages of working together, supporting each other and talking to a peer writing tutor. Academic writing should not be a lonely process but a social one. It can actually be fun if one chooses the right atmosphere, writes in the company of others, structures the work by including breaks and eats healthy food. In summary, we wanted to give students the opportunity to experience writing in a different way.

This event does not only reflect the spirit of our WC but also our philosophy. Throughout the long night our peer writing tutors were available for questions and counseling sessions. The 'tutors of duty' were changing regularly, so that everyone from the WC staff fulfilled the task at some point during the night. Peer tutoring in writing is the heart of our WC. It works according to the drop-in system. Students have the chance to talk about all aspects of writing with a qualified peer writing tutor four times a week during lunch break. The tutors are able to hold their sessions in different languages, for instance, German, English and if needed Spanish, French or Russian.

Another important idea of the night was to write together, which is supposed to work against procrastination and make the process of writing more productive. Students had the chance to talk with peer writing tutors about their process of writing as well as to exchange ideas and experiences with fellow students. Hence, new ideas were developed and concerns were shared and discussed. The unique situation of many students writing together at the same time influenced everyone in a positive way, especially those who usually lacked motivation or felt insecure about their writing.

\footnotetext{
${ }^{4}$ Referred to as the Long Night against Procrastination in Katrin Girgensohn's article 'Mutual Growing: How Student Experience can Shape Writing Centers', pp. 127-137 in this issue of JoAW.
} 
The concept of 'writing together' is strongly encouraged by the WC. Writing in groups has a positive impact on individuals' attitudes towards writing and helps to improve the text and also the writing process. Therefore, peer writing tutors offer various courses where students can work on their own writing project and at the same time progress by receiving peer feedback. Hence, one seminar focuses on students writing their BA/MA thesis. These students meet three hours every week to talk about their writing projects in groups, give feedback on texts or talk about challenges and difficulties.

In another seminar called 'Let's write!' students meet once a week in small groups to write texts using manifold creative writing techniques. Students pair up and prepare these sessions, which have 'writing different text forms in different places' as their central focus, together. This is usually the first time that students see that writing in groups can be productive and enjoyable.

For the 'Long Night of Postponed Papers' we wanted the working space to be as comfortable and cozy as possible. The WC was equipped with tables, couches and armchairs, decorated with flowers and candles. Next to the main room, a computer room provided more work space. Another room offered a fruit bar, snacks, tea, coffee, water and juice. Students could choose to work wherever they felt most comfortable. They appreciated the mixture of working atmospheres and relaxation. We considered it to be essential for productive writing to create a friendly atmosphere. A warm atmosphere is always essential for writing consultations and workshops or when students come to the WC to work on their assignments. (See Figures 1 and 2)

The kick-off for the event was at 8:00 pm. About 25 students arrived during the evening. Some of them stayed until 3:00 am and some even until 7 in the morning. Arriving students were welcomed and shown around by peer writing tutors. Before students started to work we asked each of them to write down their goal for the night on a piece of paper which they pinned onto a target on a board. Students could move their piece of paper towards the centre of the target sign each time they had completed a step in their working process. (See Figure 3.)

In order to make it through the night, breaks were necessary. Therefore, we had prepared a program. Around 9:30 pm we performed yoga at the writing table to fight the first signs of fatigue. At midnight students and tutors walked through Frankfurt in order to wake up tired minds. At 2:00 am we got together in a big circle and played a writing game. Early in the morning at 5:30 am we welcomed the sun outside. And sunny it became! At 7:00 am we had breakfast, congratulated everyone for the work they had done and served champagne.

The staff of the WC decided not only to run the 'The Long Night of Postponed Papers' but also to join the writing experience. As students and writers, we brought our own papers that we had to write. Indeed, we think that it is important to experience everything that we preach, in order to constantly develop and advance our skills. Additionally, we wanted to demonstrate that we as well still learn and experience new things about writing and that from time to time we struggle with our writing tasks. It made us proud that we received such great feedback not only from students but also from journalists who came from all over Germany to report on the event.

We started off with the funny idea to write together all night long. We ended up with spectacular promotion on some very important German media sources ${ }^{5}$ as well as new enriching experiences as peer writing tutors, team members of the WC and writers.

We learned that it is possible to write all night but that it means hard work! Writing in the company of others is, however, very motivating.

During this long night our team wrote a journal in order to capture the spirit and feelings, to reflect on our writing projects and on the night itself. The last entry said: 'We are a great team!' That was a very important experience. We could not have launched such an event as the 'Long Night of Postponed Papers' without the great teamwork that characterises the WC at the EUV. All peer writing tutors were

\footnotetext{
${ }^{5}$ http://www.spiegel.de/unispiegel/studium/0,1518,684651,00.html http://www.dradio.de/dlf/sendungen/campus/1147075/ http://www.zeit.de/2010/14/C-Schreibzentrum
} 
ready to make this night a success; everyone was willing to engage in tutoring students and to transfer the idea of the WC to students, professors, and the public. We have grown as a team, and we have realized once more that to be a peer writing tutor is not just a job but rather a profession.

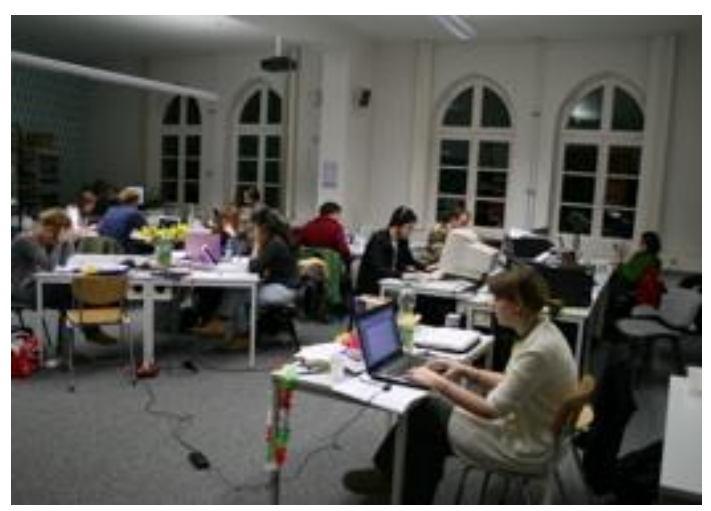

Figure 1.

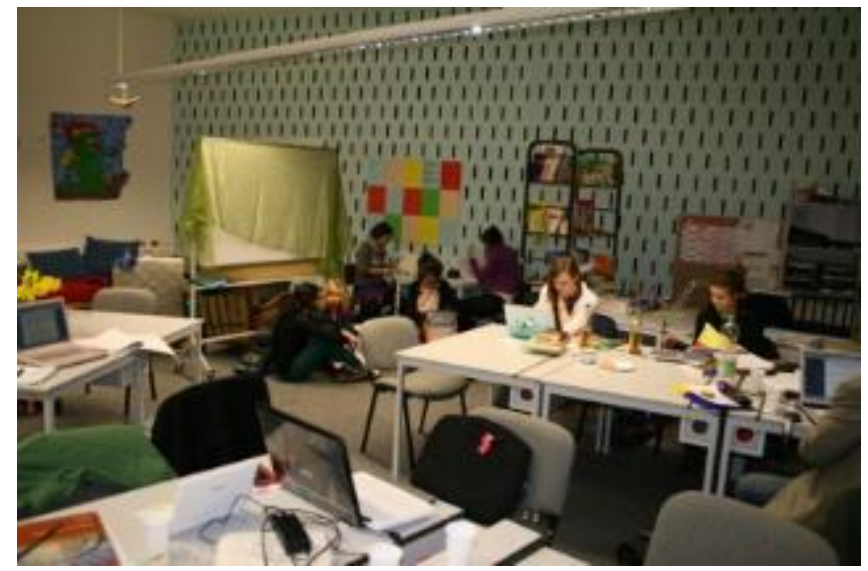

Figure 2.

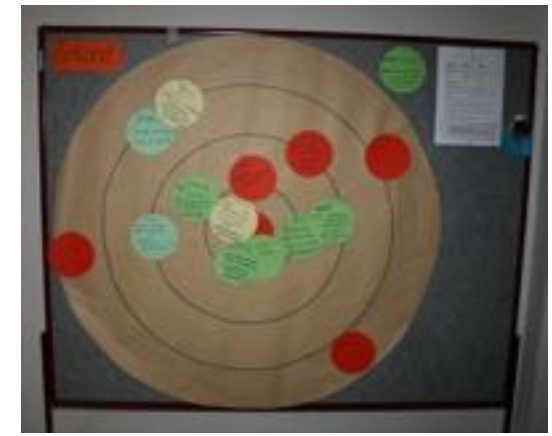

Figure 3. 


\section{Simply an Open Ear and a Second Opinion: Experiences of Peer Writing Tutors at Göttingen University}

Kai Wolf, Nils Qualmann and David Kreitz Göttingen University, Germany

Peer tutoring in writing in Göttingen is closely connected with the existence of different writing centres. Our narrative, thus, is a history of different institutions, their collaboration and their members. Our narrative would be incomplete and hard to understand, if we left this part out. Our narrative would be quite boring, if it were not for our personal stories. Our narrative would not be our narrative anymore. We will tell our history in five parts. The first part, 'Family Matters' is about our general institutional structure. The second part, 'Only one style of tutoring for everyone?' highlights borders and opportunities of discipline-specific tutoring. The third part, 'Good old times?' deals with the changes in the structure of studying after the Bologna Process and its influence on our work as peer writing tutors. The fourth part 'Tutoring = Learning' describes our understanding of peer tutoring in writing, and the last part, 'Simply an open ear and a second opinion', sums up the feedback we got from our tutees in recent years.

\section{Family Matters}

My first day as a peer writing tutor seemed to be a disaster. I was on my way to a meeting, but due to my stressful first week in the new semester, I had forgotten to look up where the building was located. At least I had made a note of the room number. After having spent half an hour in the wet and cold, I finally found the right building. I went up to the room on the second floor and because I had enough time left I started preparing for another course by reading some texts. At about 16:25, the door opened and a woman asked me if I was Kai Wolf. I assented and she told me that the course was situated in another room and that the class would already be waiting for me. I was quite embarrassed as I gathered my belongings and followed the lecturer into a room on the first floor. We entered the room together. It could only have been more embarrassing if she had taken me by the hand. I looked into a group of nice and happy faces and after the lecturer had said a few words everybody introduced her- and himself. I realised that besides me and my colleague - majoring in German Language and Literature - there were three sociology students, one political scientist, a student of ethnology, a Physical Education major, three professional writing tutors and the lecturer. There were no further comments about my being late and, while we were discussing a definition of the term writing strategy, we even had coffee and cake. From this moment I really felt at home with my new colleagues. It took some time but I later learned that, at Göttingen University, different faculties have a share in writing centre work. The Internationales Schreibzentrum (International Writing Centre) is an interdisciplinary institution, offering a variety of wac/wid courses, tutoring for students of all disciplines and training for tutors to enable them to offer discipline-specific consultations, e.g. in the German department or in the social sciences i.e. sociology, political science and ethnology. (Kai, Peer tutor, International Writing Centre)

If one of my antecessors had not known a staff member of the International Writing Centre, the 'Schreibzentrum Soziologie' (Sociology Writing Centre) would not have discovered that there are other writing tutors at the University of Göttingen. Fortunately, since 2007, we can now collaborate. (David, Sociology Writing Centre)

A common base for different writing tutors and peer writing tutors is formed by the peer writing tutor training. It leads to a common theoretical background in feedback techniques and writing as a process. In these general aspects, the domain-specific kinds of writing and coaching do not diverge. In the fields of generating new educational material, general supervision and development of the peer writing tutor training, there is also collaboration.

One style of tutoring for everyone? 


\begin{abstract}
Up to now I mostly conducted domain-specific writing tutoring with other German Language and Literature students ['German' from now on]. It's like co-working on a project with one's own knowledge and skills. One is familiar with most of the text forms in the domain - mostly specific kinds of term papers - and therefore one knows what it means to sum up common scientific research on a certain topic, formulating and pursuing an own point of interest, doing a corpus analysis or comparing different texts. One is able to comment on parts of a text, on the structure of the text and also on ideas or concepts. Of course one does not know German literature in its entirety - nor every linguistic or literary theory - but one has dealt, at least, with the main concepts and works in his own academic studies and has not to be ashamed if he looks something up for the next meeting. (Kai, Peer tutor, International Writing Centre)
\end{abstract}

One might ask if it is sufficient to have one writing centre for all the disciplines or, uniquely, peer writing tutors in each of the disciplines, or both. But what is this combination good for? To get an idea of the synergetic effects such an institutional structure allows to unfold, we would like to highlight how the approaches of tutoring writing in the disciplines and across the disciplines complement each other.

Even though I tutor in my own discipline, I think not tutoring in one's own major helps a tutor and his tutee to concentrate on the writing process itself - and not slip into topic-related discussions. Tutors and tutees should be more focused on the issue of writing a term paper or whatever text is at hand. In my experience, it is oftentimes useful to reduce students' difficulties to the level of writing skills and techniques. This is enough to help them to start or continue writing. (Kai, Peer tutor, International Writing Centre)

You can have a completely different experience when students struggle with the uses of 'l', the correct citation, and the style of writing in their own discipline. Students feel more at ease with answers to discipline-specific questions when it comes from a person who actually studied the same. And I do have to say that I just couldn't overlook an interpretation of a sociological theory that is obviously wrong. (David, Sociology Writing Centre)

Concerning the reflection and knowledge of writing strategies and feedback on texts, tutoring across the disciplines focuses particularly on the complex procedure of writing and takes a distancing position on the content of the text. Students thus can more fully concentrate on writing itself which reduces the complexity of the writer's situation.

In the disciplines, the tutors' distance from the content of the students' texts shrinks. An advantage for students can be that the tutors use their knowledge of the writing process and the discipline related knowledge to directly work on applicable strategies for their tutees specific writing project instead. Peer tutoring in writing in and across disciplines makes it easier to aid individual tutees, thus it is possible to tutor in teams or if need be, to send students to a discipline-specific tutor or somebody specially trained in tutoring writing in an intercultural situation.

Because writing centre work is spread out across different departments, the funding of tutoring and teaching academic writing does not depend on a single departmental decision. Writing centre work at the departmental level is anchored in the disciplines and the tutors are close to other staff, who recognise and approve of the benefits of writing centre work. Public relations are easier because of the access to different staff in different disciplines.

\title{
Good Old Times?
}

Writing my first paper ever at university, I wrote according to the information of friends and my school experience. First I gathered material and then I just kept writing 28 pages because this was the standard - my friends had told me so. When I was handed back the paper my Prof. commented that he regarded the content as excellent but that the formal requirements weren't met. On one hand, I had regarded my information and writing skills as sufficient, but on the other hand nobody in my discipline had informed students about the formal requirements of term papers. After this experience I always recognised the formal requirements but never reflected on the writing itself. (Nils, Peer tutor, Sociology Writing Centre) 
This was before the B.A. and M.A. changed higher education in Germany. In our experience, students had previously been able to experiment and develop writing skills and strategies without the disadvantage of every single paper counting toward their final grade. Today's student experience is different. In the schoollike atmosphere of the B.A. and M.A., almost every written work is graded, thus writing is an essential skill students need to do well in order to succeed in their studies. Nils kind of wrote into the blue and asked friends and professors for help - just as students nowadays do. But he was aware that his first steps would not be graded. Writing skills are often not taught at university because they are supposedly learned at school. Experience and research stress the lack of writing skills of university students. The socialization of today's B.A. and M.A. students into academic writing is our task as peer writing tutors. 'If we do not find efficient ways to solve this discrepancy and educate proficient student writers, no one will' (David, Sociology Writing Centre).

Kai speaks from experience when he claims that the office hours of professors are often not as helpful as students desire them to be:

In my second year as a master student, I had to write two term papers, 18 pages each. I could have anticipated that these were going to cause some problems. Firstly, I went on a three week vacation. Back home, I figured I had seven weeks left to get my writing done. For my first paper I emailed an outline to my professor. Secondly, for one and a half weeks, nothing happened. He was on vacation as well. In his answer, he told me the outline would be ok. Thirdly, I was doing a discourse analysis, which I had never done before. It took me forever to define and then use this method. I couldn't even talk to my professor about this problem, because his office hours were completely overbooked during the break. Thus, I just gathered what I had written so far, gave it a structure and got a bad grade. It still enrages me that I myself had no peer writing tutor to turn to. (Kai, Peer tutor, International Writing Centre)

\section{Tutoring $=$ Learning}

In the beginning I felt like a teacher, like somebody telling the students how to write correctly. Nowadays the feeling in tutoring sessions has changed into being partners, cooperating in a writing project. Tutees have to develop their own ways of fulfilling the tasks before them and the tutor helps them to find their own individual way to do this. Tutoring writing and being trained in tutoring skills and the theories of academic writing lead to acknowledgement of the complexity of writing. I came to understand that knowledge in the discipline does not suffice when completing a task as difficult as academic writing. Furthermore, planning and reflecting on one's own writing is necessary to succeed. Working as a tutor, I realised the importance of knowing my own habits and skills of writing, as well as planning a term paper as if it were a complex project requiring discipline specific knowledge, skills of writing and competencies of planning. (Nils, Peer tutor, Sociology Writing Centre)

Being tutored in writing by peers is a special approach offering certain opportunities for the peer writing tutors as well as the tutees. First of all, this tutoring takes place at eye level, lowering fear, nervousness and insecurity concerning personal questions and problems. Peer writing tutors are closer to the student than a professor could ever be but distanced enough to guarantee more objectivity than friends or fellow students. Although the peer writing tutor is a fellow student as well, $s /$ he has been trained in how to approach academic writing, a fact well known to the tutees.

The tutoring process works in both ways: in this setting of collaborative learning, both the peer writing tutor and tutee gain new insights into writing skills and their discipline. For example, being a peer writing tutor can change one's self perception - as Nils has experienced.

\section{Simply an open ear and a second opinion}

We just outlined the positive effects for the peer writing tutors: awareness of the writing process, of their own potentials and also their own problems. The same achievements are experienced by the tutees.

Just having some independent reader going over my work pointing out sentences and explanations that just didn't make sense to anybody without intimate knowledge of the topic was so helpful in doing some necessary changes I myself would've overlooked. And I actually learned a lot from the tutor's knowledge on spelling, grammar and punctuation. Once again: Thank you. (Tutee of the International Writing Centre) 
It is always a pleasure to have a look at the student evaluations of the Sociology Writing Centre:

- nice atmosphere, the tutor spontaneously had time for me and, actually, a lot of time

- nice, friendly, competent - as always

- I could show up with every problem at hand and even the smallest details

- Flexibility, interest in my topic, new insights, and ideas for my outline

- Team-tutoring was great, I got 2 opinions and can pick and chose on how to continue

- Openness between the tutor and me

- Very personal and individual tutoring, experience in the discipline

- Just time for me and my project...

I could actually continue this for a few pages - but Kai just told me to stop. I guess the reader got an idea why we love this job. (David, Sociology Writing Centre)

According to this feedback and our experiences, the most important aspect for the students is that somebody takes a lot of his or her time to bother with their writing projects. Tutees value somebody who simply listens to their thoughts and, if they feel stuck in the situation of writing, they appreciate a second opinion on their work without someone just pointing out mistakes or problems or correcting them. In the writing centre the students feel safe to voice their questions and do not fear failing because the peer writing tutor is not the one grading them but a co-operator in the writing process. We know that this is what the students experience because they evaluate each tutoring session as well as give personal feedback to their tutor.

Peer tutoring in writing inside or outside one's own discipline is thus a collaborative learning process involving the bilateral growth of skills. Tutors and tutees improve their knowledge of the techniques of writing, of (discipline specific) norms and requirements and, at the same time, they learn how to use their resources, connecting them with new fields of scientific work. Not only is their academic work enhanced; their social competences and their abilities to work cooperatively and collaboratively are also developed.

The Göttingen Model of Writing Centre Work aims at establishing a discipline-specific tutoring writing program within every interested faculty at the university: creating a network of collaborative learning. 


\title{
Being a Peer Writing Tutor: Reciprocal Learning Processes at Work
}

\author{
Lisa Breford, Sara Buggy, Yvonne Diggins and John Mulvihill, with contributions from Louise \\ Hollywood and Ann-Marie Keegan \\ Regional Writing Centre, University of Limerick, Ireland
}

The Regional Writing Centre (RWC) at the University of Limerick (UL) was opened in 2007, with the aim of offering support and assistance to all students in the development of their academic writing skills. The RWC offers a variety of writing services for undergraduate and postgraduate students; however, one-toone peer tutoring in writing epitomises the RWC's ethos, which is to provide students with the confidence and skills to carry out competent academic writing and to facilitate students in finding their own answers to academic writing queries (Regional Writing Centre 2011a). We, the peer writing tutors of the RWC, are proud to be an integral part of this service.

Currently, our writing centre has eleven undergraduate and postgraduate peer writing tutors from multiple disciplines. This mixture of undergraduate and postgraduate peer writing tutors from multiple disciplines is pivotal to the achievement of our writing centre's goal to deliver a variety of views and skill sets to the students of this University. The main difference between our undergraduate and postgraduate peer writing tutors is that the former were provided with training for the purpose of becoming peer writing tutors by the RWC, whereas our postgraduate peer writing tutors draw primarily on their own student and academic experiences when it comes to peer tutoring in writing (Regional Writing Centre 2011b). We feel that working as peer writing tutors has influenced us in several ways and can be best described as a circular process (see Fig 1).

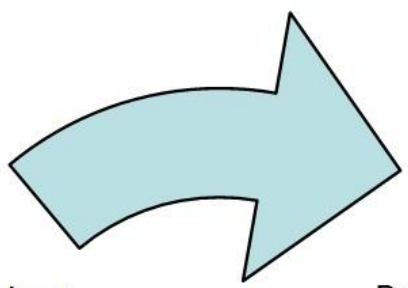

Our own student experience as an undergraduate \&

Peer tutoring in PhD student the Regional Writing Centre

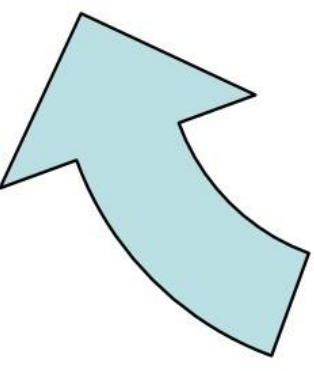

Reflection / new

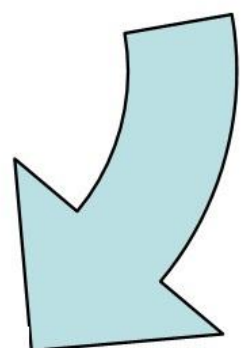

insight on our own

work

Figure 1.

Undoubtedly, all of these points differ among the members of our group; however, there are certain aspects with which we can all identify. When we started working as peer writing tutors, we all initially worried that we may not have the answers to the different questions and queries that students may have. Although we knew that our writing skills were good, we had not worked in such an environment before. While we quickly settled into the process of helping and guiding others in finding their own answers, this aspect of peer tutoring in writing still provides us with new challenges on a daily basis. It is not always easy to make students realise that our role is not to fix the problem for them, but to be active listeners, 
thus providing them with the skills and tools to solve it themselves (Ryan and Zimmerelli 2010). Sometimes, we cannot communicate to students the value of learning to help themselves effectively, and this can be quite a frustrating experience.

However, it is extremely rewarding when we do form a connection with a student. The positive feedback that we receive from satisfied students is extremely gratifying for a peer writing tutor working in the RWC. To see the transformation of a student who came in nervous and lacking confidence into someone who has gained new self-belief in his or her ability to write is guaranteed to brighten up our day. Not only is it uplifting to see them leave in good spirits, but it also gives us renewed confidence in our own abilities. For example, while we, the peer writing tutors, may as students have once felt unable to tackle that new chapter of our PhD or essay, we now realise that we have all the skills and tools necessary and that we simply need to follow the methods and advice that we provide to students we meet in our writing centre.

Hence, we view our work at the RWC as a symbiotic process, as we learn from the students that come in and we hope they learn from us too. For example, we find that we are now much more cognisant of our personal writing styles, along with our strengths and weaknesses as writers. We can easily identify how we progress through each different writing phase and we are not afraid or embarrassed to ask for help or to share pieces of writing with peers to review (Ryan and Zimmerelli 2010: 41-57). We have a good sense of what constitutes competent writing and know how to measure it, frequently taking advantage of the benefit of being able to share our work with other peers. Accordingly, as students, we are now much more aware of the importance of the social aspect of writing, as it is within social and non-threatening environments similar to the RWC that we write best.

Additionally, through our work at the RWC we have learned how beneficial it is to interact with students from completely different age groups, disciplines and backgrounds, as we benefit from their differing perspectives every day. For example, for one member of our group, one very important factor turned out to be the fact that she is a non-native speaker of English who has attended universities in Germany, Canada and Ireland. This experience proved to be extremely helpful, especially as many international students visit the Centre. Having gone through the transition period into the Irish university system herself, it is easy for her to relate to their problems and worries: 'What do lecturers expect at this university? Which structure for an essay is most suitable?' All of these questions can easily become overwhelming and in such situations sometimes simply talking to someone who has been in the same situation can be an enormous help. For another member, changing disciplines when transitioning from her M.A. to her $\mathrm{PhD}$ research reminded her just how daunting it can feel when you are expected to begin writing in a way that is unfamiliar to you, and helped her to see that the tactics that she had shared with other students in the RWC can be useful at any stage in the writing process. In our writing centre, students are provided with an audience for their work that has only one intention: to help the student harness their true potential as a writer (Ryan and Zimmerelli 2010: 17-40). Additionally, the peer writing tutors, especially those of us who teach tutorials in the university, benefit from being given the opportunity to learn about the students' perspectives on assignments without actually being involved in the assessment. It is clear, then, that the learning processes which are at work in the RWC are not only reciprocal but also multileveled, comprising different elements from topics as varied as formatting and structure to anxiety and writer's block.

Overall, being a part of the RWC means that we feel like a more significant part of the university community, as we are contributing both as students and as peer writing tutors. As a student, it is easy to feel detached or lost in the big institution of a university: as an undergraduate you may at times be treated as merely a number, while as a PhD student your existence is likely to be very isolated. However, working as peer writing tutors makes us feel part of the university on many levels: we are part of the team of peer writing tutors, which is an essential part of the writing centre, which in turn is an integral part of the university's infrastructure. In addition, as peer writing tutors we meet new people every day and as most of them return, they come to recognise us outside the centre. This means that we are greeted by a growing number of students around the campus. Although this may only consist of a 'Hello, how are you?' it makes the campus feel more welcoming and reminds us that we are not just anonymous faces in the crowd.

For the future, we feel that although our writing centre is working extremely well, with increasing numbers of students visiting us and many choosing to return, we, as peer writing tutors, would like to make two suggestions, which may help to improve our centre. Firstly, we suggest the development of initiatives that help to encourage students from disciplines that may undervalue the importance of writing to utilise the RWC and to understand how writing can benefit their career paths, undergraduate and postgraduate 
programmes. We suggest that peer writing tutors in these disciplines should advertise the services and supports of the RWC through email and announcements in lectures. Secondly, we hope to encourage students to give us increased feedback on our own performance. Hopefully, by then taking this feedback on board, we can continue to improve the centre, ensuring that it remains entirely student-centred, and that we continue to give and receive to the utmost of our ability. This way, when we leave UL we can look back and know that we have learned, we have contributed, and we have gained valuable life experiences.

\section{References}

Regional Writing Centre (2011 a) About the Writing Centre [online] available from $<$ http://www2.ul.ie/web/wWW/Services/Centre for Teaching \%26 Learning/The Writing Ce ntre/ABOUT THE WRITING CENTRE> [20 October 2011].

Regional Writing Centre (2011 b) Working for the Centre [online] available from $<$ http://www2.ul.ie/web/WWW/Services/Centre for Teaching \%26 Learning/The Writing Ce ntre/WORKING FOR THE CENTRE> [20 October 2011].

Ryan, L. and Zimmerelli, L. (2010) The Bedford Guide for Writing Tutors. $5^{\text {th }}$ edn. Boston: Bedford/St. Martin's. 